\title{
Correction to: Chromatin insulation dynamics in glioblastoma: challenges and future perspectives of precision oncology
}

\author{
Borja Sesé* (1), Miquel Ensenyat-Mendez, Sandra Iñiguez, Pere Llinàs-Arias and Diego M. Marzese*
}

\section{Correction to: Clin Epigenet (2021) 13:150 https://doi.org/10.1186/s13148-021-01139-w}

Following publication of the original article [1], the authors identified an error in the Funding section.

The section currently read:

This work was supported by the Instituto de la Salud Carlos III Miguel Servet Project (\#CP17/00188) and AES 2019 (\#I19/01514), the Institut d'Investigació Sanitària Illes Balears (FOLIUM program), the Govern de les Illes Balears (Mar- galida Comas program), the Fundación Francisco Cobos, and the Asociación Española Contra el Cancer.

The section should read:

This work was supported by the Instituto de la Salud Carlos III Miguel Servet Project (\#CP17/00188) and AES 2019 (\#PI19/01514) co-funded by European Regional Development Fund "A way to make Europe", the Institut
d'Investigació Sanitària Illes Balears (FOLIUM program), the Govern de les Illes Balears (Margalida Comas program), the Fundación Francisco Cobos, and the Asociación Española Contra el Cancer.

The original article [1] has been corrected.

Published online: 19 October 2021

\section{Reference}

1. Sesé B, Ensenyat-Mendez M, Iñiguez S, Llinàs-Arias P, Marzese DM. Chromatin insulation dynamics in glioblastoma: challenges and future perspectives of precision oncology. Clin Epigenet. 2021;13:150. https:// doi.org/10.1186/s13148-021-01139-w.

\section{Publisher's Note}

Springer Nature remains neutral with regard to jurisdictional claims in published maps and institutional affiliations. to the material. If material is not included in the article's Creative Commons licence and your intended use is not permitted by statutory regulation or exceeds the permitted use, you will need to obtain permission directly from the copyright holder. To view a copy of this licence, visit http://creativecommons.org/licenses/by/4.0/. The Creative Commons Public Domain Dedication waiver (http://creativecommons.org/publicdomain/zero/1.0/) applies to the data made available in this article, unless otherwise stated in a credit line to the data. 